\title{
The interface between health sector reform and human resources in health
}

\author{
Felix Rigoli*1 and Gilles Dussault ${ }^{2}$
}

Address: ${ }^{1}$ Regional Adviser, Human Resources Development Program, Pan American Health Organization/World Health Organization, Washington, DC, USA and ${ }^{2}$ Senior Health Specialist, World Bank Institute, Washington, DC, USA

Email: Felix Rigoli* - rigolife@paho.org; Gilles Dussault - gdussault@worldbank.org

* Corresponding author

Published: 03 November 2003

Human Resources for Health 2003, 1:9
Received: 17 October 2003

Accepted: 03 November 2003

This article is available from: http://www.human-resources-health.com/content/I/I/9

(C) 2003 Rigoli and Dussault; licensee BioMed Central Ltd. This is an Open Access article: verbatim copying and redistribution of this article are permitted in all media for any purpose, provided this notice is preserved along with the article's original URL.

\begin{abstract}
The relationship between health sector reform and the human resources issues raised in that process has been highlighted in several studies. These studies have focused on how the new processes have modified the ways in which health workers interact with their workplace, but few of them have paid enough attention to the ways in which the workers have influenced the reforms.

The impact of health sector reform has modified critical aspects of the health workforce, including labor conditions, degree of decentralization of management, required skills and the entire system of wages and incentives. Human resources in health, crucial as they are in implementing changes in the delivery system, have had their voice heard in many subtle and open ways - reacting to transformations, supporting, blocking and distorting the proposed ways of action.

This work intends to review the evidence on how the individual or collective actions of human resources are shaping the reforms, by spotlighting the reform process, the workforce reactions and the factors determining successful human resources participation. It attempts to provide a more powerful way of predicting the effects and interactions in which different "technical designs" operate when they interact with the human resources they affect. The article describes the dialectic nature of the relationship between the objectives and strategies of the reforms and the objectives and strategies of those who must implement them.
\end{abstract}

\section{Background}

The interface between sector reform and human resources in health: a conceptual framework

The potential and actual impact of health sector reform on the health workforce has been highlighted in several studies [1-4]. Less work has been devoted to explore individual and collective reactions to reform attempts by workers. Understanding these reactions and their effects is important in assessing whether reforms can effectively reach their goals, since human resources factors can obstruct technically well-designed reforms and consequently deprive populations of their potential benefits.
Human resources are often considered just another type of input, like financial or physical resources [5], but this might prove wrong or at least too narrow a view. People working in health services are not exclusively "instruments" for delivering necessary health care $[3,6]$. They are strategic actors [7], who can act individually or collectively to modify the governments' projects, such as trying to impede budget cuts, which they present as a strategy to protect the quality of services, or blocking a more equal deployment of resources, which becomes an obstacle to achieving a more equitable access to care. 


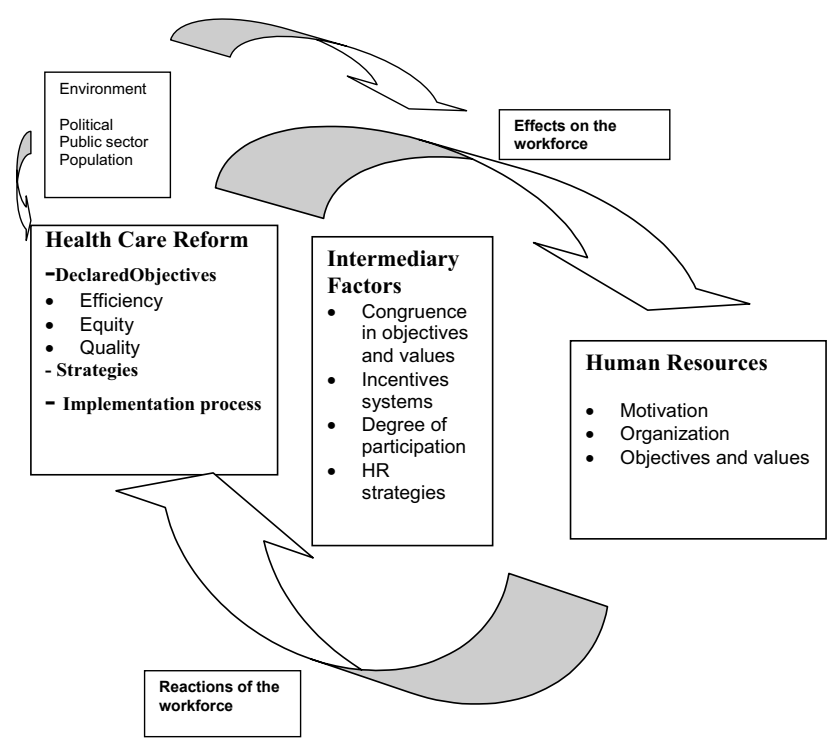

Figure I

Health sector reform (HSR) and human resources (HR).

In this paper, we propose a framework to understand the interrelationships connecting health sector reform processes and human resources, focusing successively on:

- health care reform, its declared objectives, how it is implemented and its impacts on the health workforce

- human resources' reactions to reforms, at the individual and collective levels

- the intermediary factors that influence the effects of reform and the responses of the workforce.

The proposed framework is schematically represented in Fig. 1.

The analysis of the interrelationships between these factors provides a useful tool to predict the effects of different "technical designs" on the human resources they affect. This article intends to show the dialectic nature of the relationship between the objectives and strategies of reforms and the objectives and strategies of those who are expected to implement them. It tries to identify the gaps in knowledge about the determinants of workforce participation, whether in the form of collaboration or opposition to systemic changes.

The policy design implications of understanding these interactions can help to integrate human resources strategies into the health reform process and to construct a bet- ter institutional capacity for human resources development.

\section{Discussion}

Health sector reform: objectives, strategies and effects

Health care systems in most countries, rich and poor, have undergone reform processes stimulated by a growing concern about the weak correlation between the volume of resources expended and the outcomes in terms of health status. These reforms were usually embedded in a set of government reforms intended to improve the efficiency, equity of access and quality of public services in general [8], http://www.americas.health-sector-reform.org/eng lish/, http://www.euro.who.int/observatory/toppage. In many instances, however, these reforms actually focused on a single macroeconomic objective, that of reducing the government's operating costs and cutting budget deficits, without paying much attention to their other declared objectives. It is not the purpose of this article to critically look at the health sector reform movement, since there is an ample literature devoted to it [9-11].

Although each country's reform process has its own specificity, there are common trends, such as the pursuit of better outcomes in terms of quantity and quality of services using the same or fewer resources, which has become known as "getting more value for money." In the health sector, these objectives are commonly expressed in terms of improving equity of access to services, effectiveness of care, efficient utilization of resources, satisfaction of users, and sustainability. The emphasis varies, however, depending of the economic conditions and the political environment of the country. Here we will focus on the equity, efficiency and quality objectives, as they tend to be common to all health reform processes. We refer to these objectives as "declared objectives," recognizing that, in practice, reform processes can be driven by other motives and objectives, while still using the language of equity, efficiency and quality.

\section{Efficiency}

Efficiency is a relative concept: an intervention is more efficient than another in producing the same output. There is ample consensus in the distinction between "technical" efficiency and "allocative" efficiency: the former refers to productivity or to the best use of resources for extracting the maximum output from given inputs; the latter is concerned with choosing the interventions that produce the greatest benefits to health, at a given cost. Efficiency is a standard declared objective of reform in the public sector and in particular in the health sector. Many reform processes are led by the economic national authorities, and are focused on public budget reduction, on changing the relative weight of fixed and variable government expenditure, and on producing better services with 
the same (or fewer) resources. To achieve this, various approaches that directly affect human resources have been tried. The following tend to be the most common.

Budget-oriented reforms have tried to limit the central government expenditures by decentralizing social and health services at the local, provincial or municipal level to achieve efficiency gains and reduce deficits at the central level. Regardless of good intentions, the evidence indicates that the local levels were ill-prepared to manage the new responsibilities devolved to them [12], especially where this occurred in a context of decentralization without adequate budgets and appropriate tools [13]. This often led to increasing inequalities, while achieving little in terms of efficiency.

Another frequent approach has been to convert fixed (labor) expenditures in variable costs, by outsourcing services, particularly those of the non-clinical workforce (cleaning, laundry), but also the more technical services [14]. The following forms of contractual relationships have been identified [15]: Contracting out, where only private bids are allowed and where contracts may be agreed with or without a competitive process; Performance contracts, which are explicit agreements between the government and public sector managers; Internal markets, where there is complete separation between the roles of purchaser and provider within the public sector, and links through trading agreements or contracts. Competitive tendering (also known as market testing), where internal staff can bid for contracts in competition with private contractors; Internal contracting, where only internal bids are allowed.

The search for efficiency also included strategies to change the burden of labor costs in the financial equation. The importance of personnel expenditures (60 to $70 \%$ of all sector expenditures) has made this item a favorite target. As a result, downsizing has been practiced in many countries, even though health services remain a labor-intensive product with little room for labor substitution. In addition, technological changes frequently generate demand for new specialized personnel. Another strategy particularly used in more costly settings, such as hospitals, has been re-engineering, centered in reviewing the organization of work, reallocating, and sometimes reducing, personnel to augment productivity [16].

\section{Equity}

Equity refers to fairness. The equitable distribution of health care among people of different levels of income is usually called vertical equity (care should be available as a function of need, not income), while distribution among people with the same health condition or need is called horizontal equity (equal need should entail equal treatment). The ideal of equity in health care has ethical and political foundations, well described by Donabedian in his classic typology of "egalitarian" and "libertarian" value choices [17].

Strategies aiming at improving equity in relation to needs (rather than to demands) require more systematic planning of health services, including the introduction of financial protection mechanisms, the targeting of specific needs and groups and redeployment of services, which is bound to have an impact on the distribution and the working conditions of the workforce.

\section{Quality of services and users' satisfaction}

Quality can be defined in many ways, but for the purpose of this paper we retain the following definition:

- Technical quality refers to the impact of the health services on the health conditions of a particular population. Technical quality is an important dimension of the providers' performance.

- Sociocultural quality measures the degree of acceptability of services and responsiveness to users' expectations.

The road towards improving quality is full of human resources challenges, in view of the complexity of the interface between users and providers. Constraints posed by budget cuts and the lack of congruence between the reforms' and the workers' values, translate in changes in performance levels and in users' satisfaction. Absenteeism rates, low morale of health personnel (especially in nursing), and higher rates of turnover, weaken the capacity to cope with the demands of quality care [18]

\section{Health sector reform effects on HR}

The expected objectives of the reforms translate into health system changes, which can have profound implications for the workforce configuration (as seen in Table 1), which in turn induce positive or negative responses from the workforce.

Strategies to better use scarce resources, as responses to a diagnosis of wasteful utilization associated with centralized bureaucracies, led many governments to transfer the management of health services to local authorities, for better control of spending and increased accountability. Where decentralization included transfer of human resources, local authorities had to play a new role as employers, often without the appropriate technical abilities or even the funding to do so.

In hospitals and other tertiary services, the objective of reducing or stopping the growth of fixed costs often led to substituting the internal provision of some services with 
Table I: Workforce implications of health sector reform

\begin{tabular}{ll}
\hline Objective/Proposed changes & Workforce implications \\
\hline Efficiency/Decentralization & Decision power and authority transferred. \\
& Transfer of personnel administration and budget \\
Efficiency/Outsourcing, privatization & Changes in contracts and working conditions \\
& New institutional arrangements, threat to the power of trade unions \\
Equity & Geographical and public/private redeployment \\
Quality, user's satisfaction. & New recruitment and retention mechanisms \\
& Changes in the qualifications/skills/attitudes needed. \\
& New work configurations (ex. teamwork) \\
& Balance of power between health personnel and users changed \\
\hline
\end{tabular}

(Adapted from Dussault \& Dubois 200I [29])

external contracting. This measure resulted in changes in the number of permanent staff and flexible, therefore less predictable, contractual relationships with a growing part of their workforce.

Strategies designed to promote equity usually aim at the extension of coverage of underserved population groups, through making accessible an "essential package" of services, defined according to cost/benefit or cost/effectiveness criteria. This implies the availability of human resources in rural and impoverished areas, with primary health care skills and orientation, which in turn creates the need for new ways of recruiting and retaining of health professionals in areas and services where conditions are not perceived as attractive. Efforts to achieve greater technical and perceived quality usually take the form of upgrading the qualifications and trying to change the attitudes of key health providers, and of introducing new teamwork configurations, mainly through training $[19,20]$. Training activities are meant to align the workers' values and attitudes with the declared objectives of the reform process. They tend to be liked by reformers because they are visible to the public and seen positively - although not always for the right reasons - by workers, for instance when it means merely an opportunity to collect per diems, or to travel.

\section{Effects of decentralization strategies}

Changes in deployment and labor conditions following decentralization generally have two consequences on human resources:

- The new organizational structures mean that the role of employer, and consequently the union's organizations, are transferred to regional levels. The previous relationships must be reconfigured, with new actors who then must adapt their conduct to the new situation [21].
- The transfer of human resources functions without a comprehensive design of the financial transformations required may lead to deeper inequities, as local units are left to provide the services with locally collected resources [13].

\section{Effects of outcontracting strategies}

Outcontracting labor-intensive activities is affecting the legal framework of labor conditions in the civil service $[22,23]$. This can be perceived as a threat by the workforce executing the tasks targeted by the outcontracting process. While outcontracting to external bidders is likely to imply layoffs and modifications of the functions of involved workers, the creation of an internal market can lead to a process of cooperative work, without the radical changes in working conditions implied by external outcontracting [15]. In both cases, there is a potential conflict between the workers' interests and the efficiency goal, as competition offers a means to achieving "technical" efficiency while at the same time threatening employment stability.

\section{Effects of equity oriented strategies}

The need to deploy the workforce in line with the requirements of the burden of disease in a country or a region has deep human resources implications. In an ideal world, staffing would be guided by the needs of specific population groups. In the real world, geographical equity in the deployment of health human resources has always been a difficult task everywhere. Attempts in that direction easily induce personal and collective blocking strategies, which calls for a gradual, long-term approach $[24,25]$.

Improvements in labor-intensive sectors, such as extending primary health care, require the active collaboration of providers, and their involvement and support to the process is a key factor of success. This is why governments generally end up making concessions to avoid their opposition to reforms and to make their implementation 
more feasible. But doing so might limit the expected impact of reform [26].

\section{Effects of quality oriented strategies}

Research on the influence of reforms targeting the organizational environment shows that health workers who have experienced job restructuring hold substantially more negative views about the impact of reforms on patient care than those who have not [27]. Staff reductions can have effects on quality indicators, such as those measured by the Outcomes Potentially Sensitive to Nursing (OPSN) index. A study in a large sample of hospitals in the United States found a relationship between the reduction of nursing staff and patient outcomes, in terms of an increased length of stay for four medical conditions [28]. These research results seem to confirm the influence of balanced staffing on the technical quality of services, but there is a paucity of evidence about its effects on users' satisfaction (perceived quality).

\section{Workforce reactions to health sector reform}

In labor-intensive industries such as health services, the importance of capital and technology is high, but never as much as the knowledge, attitudes and efforts developed by the persons in direct contact with the final users. This justifies a closer look at workers' reactions to changes resulting from reforms that can be regarded as changes in the rules of the employer-employee relationship [29].

\section{Individual responses}

This section discusses the reform-workforce interrelationships at the individual level, focusing on answers to changes in the incentives system, motivation factors and their consequences on the "psychological contract" between workers and the health care system.

Many studies in the service industry show how provider characteristics have the strongest influence on overall customer satisfaction. Service providers not only deliver and create the service but are often perceived as synonymous with service quality by the customer [30]. Services have been described as a "deed, act or performance," or as "encounters in time," rather than physical objects. The engagement of providers can help create a climate where autonomy, flexibility, and continuing learning add value to the quality of services by ensuring that they are continuously adapted to changing needs [31].

The economics literature defines human capital as the productive capabilities of people [32] and, within this definition, skills, experience and knowledge have economic value for organizations as factors contributing to productivity and to adaptability. Like other assets, human capital has value in the marketplace, but unlike other assets, the potential value of human capital can be fully realized only with the cooperation of the person. Therefore, all costs related to eliciting productive behaviors from employees, including those related to motivation, monitoring, and retention of personnel, are human capital investments from which returns can be derived. In human capital theory, contextual factors such as market conditions, unions, business strategies and technology draw their relevance from their effect on costs associated with alternative approaches to using human resources development to increase the value of the organization's human capital and the value of anticipated returns, such as productivity gains.

\section{Responses to new incentives systems}

Many reform interventions introduce some kind of linkage between pay and performance, through different arrangements in line with shifting from fixed to variable costs. Few of these schemes have been thoroughly evaluated [33], but the primary findings point to failure to achieve the expected results, and in many cases, the production of effects quite different from those foreseen by the planners of the incentives scheme $[3,34]$.

The paradoxical results of new incentives systems that tried to modify the behavior of physicians show that physicians are capable of autonomous reactions, other than those predicted by economic theory. Even the most sophisticated mechanisms for paying physicians merely attenuate, and do not eliminate, overtreatment, undertreatment and other socially undesirable behaviors created by fee-for-service, capitation and mixed methods of payment. Moreover, sophistication in the design of payment incentives creates its own pathologies [35]. The limits of payment mechanisms explain the importance of non-price methods for motivating appropriate behavior, such as screening and selection, explicit prescription of desired performance, monitoring of compliance and inculcation of new norms and cultural expectations [36]

With technical non-medical employees, who are usually paid by salary and have poorer career prospects, the absence of more sophisticated incentives can lead some to opt out of the health sector. As it becomes perceived as conservative, not innovative and overly bureaucratic, the health care sector finds it more difficult to attract and retain good personnel, as is already the case in the area of information systems and e-business. While other parts of the economy are growing at a faster pace, health care's reluctance to incorporate new technology will force it to pay above-market wages, adding to costs that are already regarded as high, and broadening internal differences in an already unbalanced income distribution range [37]. 


\section{Impact of new working conditions on motivation}

A few studies have focused their work on the changes in attitudes and efforts of health workers in response to the exigencies imposed by the new rules created by the reform process $[25,38,39]$. The extent to which workers accept and share the proposed institutional changes seems to affect their motivation. Two interrelated psychological streams operate in the work motivation process:

- The "will do" component: the extent to which workers adopt organizational goals.

- The "can do" component: the extent to which workers effectively mobilize their personal resources to achieve joint goals [40].

Motivation can be enhanced or blocked, according to the following:

- The importance of goals' and values' congruence between workers and the organization.

- Efforts made to ensure that organizational goals are clear and that workers see the benefits of working towards these goals.

- Multiple channels influencing motivation: focusing solely on financial incentives is not likely to produce the desired results [39].

The congruence between organizational goals, system of incentives and reform values is especially important in the public health services, since it is perceived as a means to distribute valued public goods. Health professionals, who have internalized an ethos of public service, may resist the drive towards efficiency or cost-cutting measures, perceiving it as clashing with their own system of values.

\section{Consequences on the psychological contract}

The link between organizational objectives and personal motivation is the "psychological contract" between the individual and the organization. This notion describes a reciprocal relationship defined by the mutual expectations of the individual and the organization. The psychological contract is usually unwritten and unspoken, but nevertheless represents each party's expectations for the relationship's continued existence. For many individuals, the psychological contract includes an intrinsic belief that their work will give them a fulfillment through selfactualization, a sense of achievement, recognition, responsibility and the quality of personal relationships in the workplace [25].

New professional roles and new working conditions can break the psychological contract between health institu- tions and their workforce. For example, a survey on nurses' response to changes showed that those who had experienced reform-related mergers or restructuring held more negative perceptions of the climate for patient care than those who had not been through a merger, although the relationship was less strong than it was for restructuring. Nurses with a negative perception expressed an aspiration to have a greater voice in the organization and staffing of hospitals; they also showed a greater readiness to unionize [27].

Flexible arrangements, layoffs resulting from reduced budgets, and payment mechanisms tied to performance have replaced the ethos of hard work, security and permanence of work. But the attitude of individuals has also changed. In an environment where there is no long-term guarantee of employment, different employee attitudes emerge, characterized by greater emphasis on protecting self-interest [38] and greater readiness to use legal means for that purpose [41].

\section{Collective responses}

Some form of worker cooperation is needed to transform the institutional changes into expected results. Where there are strong unions and professional associations, these are key actors in the political economy of reforms almost by definition. A unionized workforce is more capable of maintaining wage levels, but not necessarily employment levels. A review of the situation in the United States in the 1980s showed that unionized employees have received wages estimated at 33\% higher than nonunion employees. Unions were often credited with improving working conditions and safety [42].

The interests of the public service workers are usually expected not to clash with the interests of the citizens. Workers in social sectors are expected to abide by codes of ethics and rules that state their rights and duties, while maintaining the right to be represented by independent and free associations conducting collective bargaining on their behalf [43]. Retrenchment measures, which are a basic tenet of the standard public sector reform package, pose a direct challenge to the livelihood of public sector employees [2], which creates a tension with the expectations described above. It is therefore hardly surprising that the experience of the public sector reform model has been characterized by the decisive resistance by the employees, leading to delays and unplanned changes in implementation.

\section{Professional associations' response}

Health professionals, and in particular physicians, are rarely organized in the same unions that represent the other public service workers, but in associations following different models of organization and behavior [44]. The 
professionals and their associations are no longer assumed to automatically abide by an ethics of public service, as might have been considered before the 1970s. They are rather perceived as active stakeholders and lobbyists in pursuit of their own interest.

The classical statement that a profession attains and maintains its position by virtue of the protection and patronage of some elite segment of the society which has been persuaded that there is some special value in its work [45] probably still stands. But in the last decades, society has become more critical of the claims of professional groups that they are primarily client/public-oriented. Professionals nevertheless continue to exercise considerable influence on the regulation of the provision of health care, through the definition of standards of practice and by participating formally or through lobbying in the process of defining the legal and administrative framework of the health sector $[46,47]$.

As a result, professional interests tend to dominate over the general welfare, creating protected labor markets, which can have negative consequences on efficiency and equity. An example is the blocking of substitution of labor by doctors refusing to delegate tasks to less extensively trained personnel, which is an obstacle to improving productivity and increasing access to services [48]. A free-market approach does not seem to correct these major imbalances, given the "market power" of the professional associations. A stronger regulatory capacity and a clear recognition of the differences between the values of the reform and the interests of the professionals may be a more fruitful approach.

\section{Nonprofessional health workers' response}

In a context of fiscal constraint, nonprofessional health workers often fear the effect of reforms on their income and work conditions, as well as on labor stability, tenure and promotion. Given the special character of health services, the cooperation of these workers is vital in improving their performance, thus making workers' organizations key actors in the political economy of reforms. The relatively high unionization rates of the public sector in Latin America and other regions, either in the form of labor unions or professional associations (when legal limitations forbid the former), facilitates the organization of collective action. Public health sector employees generally work in the formal sector and in non-tradable services. In combination with job stability clauses, these two factors reduce their exposure to competitive pressures (both domestic and international) and make them more resilient to the moderating effect of unemployment on wage militancy [26]. However, the pressures of the public services reforms have certainly had a downwards impact on unionization rates: It is not yet clear whether changes are due to general trends in unionization or to health sector reforms [43].

In Latin America, nearly all the countries have identified labor conflicts as a limiting factor of the capacity of the governments to reorganize the public health sector [49]. Even well-planned reforms, such as in Costa Rica, faced conflicts between the workers and the Social Security Fund Administration, when the union representatives challenged the new labor regulation - in terms of wages, selection, timetables and new roles of the health professionals - as unlawful and unconstitutional [23]. In Africa, relatively docile unions in Zambia were transformed into a powerful opposition to reforms when their conditions of service were threatened. The Philippines experienced similar unforeseen resistance to the devolution of health services to local governments in the mid 1990s [50].

In the United States, organized opposition of physicians and the labor movement contributed to the failure of reforms introducing managed care competition in health care in 1993. In the 1994 presidential political campaign in that country, large donor and political action committee (PAC) contributions tied to the health and insurance industry increased far faster than contributions by other industries. The American Medical Association's PAC was the leading contributor among health and insurance PACs, showing the concern and interest in influencing future administrations' health care policies [51-53].

An International Labour Organization (ILO) survey in 1998 described different collective reactions to the wave of reforms of the preceding decade. Table 2 gives country examples indicating that while physicians and nurses reacted more to systemic changes, other workers tended to react to layoffs and wage freezing.

While some of these reactions can be seen as contributing positively to the implementation of the changes, others clearly had negative effects, such as blocking the extension of primary care coverage (Israel), or jeopardizing the availability of care for the population by making tradeoffs between budget reduction and maintenance of the level of medical fees (Quebec).

\section{Intermediary factors influencing the effects of reforms and responses of $H R$}

Here we have tried to identify some of the main interrelationships between the intentions of the reformers and the strategies of those expected to implement them. To some extent, all reforms and the resulting new configuration of services are reshaped, in one way or another, by the actions of workers involved in providing care or enforcing regulations. The question for policymakers is how to 
Table 2: Collective reactions to the reforms in the 1990s

\begin{tabular}{|c|c|c|}
\hline Country & Workforce group & Industrial action \\
\hline Argentina & Doctors & $\begin{array}{l}\text { Demonstrations over linkages between changes in payment structures and health care } \\
\text { outputs }\end{array}$ \\
\hline Canada (Alberta) & Laundry personnel & $\begin{array}{l}\text { Budget cuts and administrative reorganization. Although strikes were forbidden, } \\
\text { laundry personnel stopped activities and caused a setback of the policies. }\end{array}$ \\
\hline Canada (Quebec) & Doctors & $\begin{array}{l}\text { Freezing the fee for medical procedures in the process of reducing health budget. As a } \\
\text { result, the number of available hours was reduced. }\end{array}$ \\
\hline Chile & Doctors & $\begin{array}{l}\text { Demonstrations over linkages between changes in payment structures and health care } \\
\text { outputs }\end{array}$ \\
\hline Dominican Republic & Doctors & $\begin{array}{l}\text { Demonstrations over linkages between changes in payment structures and health care } \\
\text { outputs }\end{array}$ \\
\hline \multirow[t]{2}{*}{ France } & Civil Service & Proposal of changing public service status sparked strikes and demonstrations. \\
\hline & Junior Doctors (Residents) & $\begin{array}{l}\text { Introduction of managed care and personalized medical cards were resisted by a strike } \\
\text { of junior doctors. }\end{array}$ \\
\hline \multirow[t]{3}{*}{ Germany } & Doctors and Nurses & Opposition to the government's efforts to curb health expenditures. \\
\hline & Doctors & Dispute with doctors about being accountable for prescription budgets. \\
\hline & Nurses & $\begin{array}{l}\text { Nursing organizations were concerned with deregulation of nursing workloads and the } \\
\text { consequences in the quality of care. }\end{array}$ \\
\hline Israel & Nurses & $\begin{array}{l}\text { Strike over a dispute following decentralization of } 500 \text { family health stations to the } \\
\text { municipalities without proper financing. }\end{array}$ \\
\hline Romania & Health personnel & Strikes and demonstrations about discrepancies between wage rise and inflation \\
\hline Russia & Health personnel & Local and national strikes about non-payment of wages. \\
\hline South Africa & Nurses & $\begin{array}{l}\text { Nurses went on strike for working conditions and representation in "umbrella" } \\
\text { organizations. }\end{array}$ \\
\hline Sweden & Doctors Nurses & Decentralized bargaining to counties followed by strikes of medical and nursing staff. \\
\hline
\end{tabular}

Source: ILO, 1998; Maceira \& Murillo 200 I [2,26]

influence the direction of this reshaping, so that it is consistent with health objectives and health needs.

The literature points to a number of intermediary factors that can influence both the effects of interventions and the response of workforce:

- The importance given to the human resources factor cannot be disregarded in the strategic planning and implementation of the reform process, even when the timeframe of the reforms is tight and leaves little time for lengthy consultation of stakeholders $[3,13,54]$. In one way or another, the reactions of workers will influence the process and affect the plans.

- Getting workers involved in the design and implementation of the reform is important. However, as a substitute for participation, many projects train workers on how to follow new procedures, therefore rarely achieving the purpose of creating real commitment $[19,20]$.

Participation of workers' representatives such as professional associations or unions is a necessary but not sufficient condition to successful reform design and implementation [29,55]. Clear definitions of efficiency, equity, and quality objectives are also crucial to reduce the risk that the participation process be diverted towards the self-interests of the workforce.

- A high degree of coherence between the institutional culture and values, the objectives of the reform instruments, and the tools and timetable of the implementation process facilitates the commitment of workers to the reform process $[39,56]$. Country experiences show how people who work in health services easily perceive the non-alignment between these components of the reforms [50].

- The complexities of promoting participation while preventing the conversion of the reform in a provider-led and interest-driven process call for a new role for health authorities, founded on a renewed view of public health organizations $[20,55]$, and of critical activities such as human resources planning, information systems for policy, bottom-up policy design and personnel administration.

- The implementation process is as important as a good technical design $[12,13]$. Many well-planned transformations failed because the managerial or financial tools were not adapted to the proposed changes, creating labor turmoil and opposition from workers. 


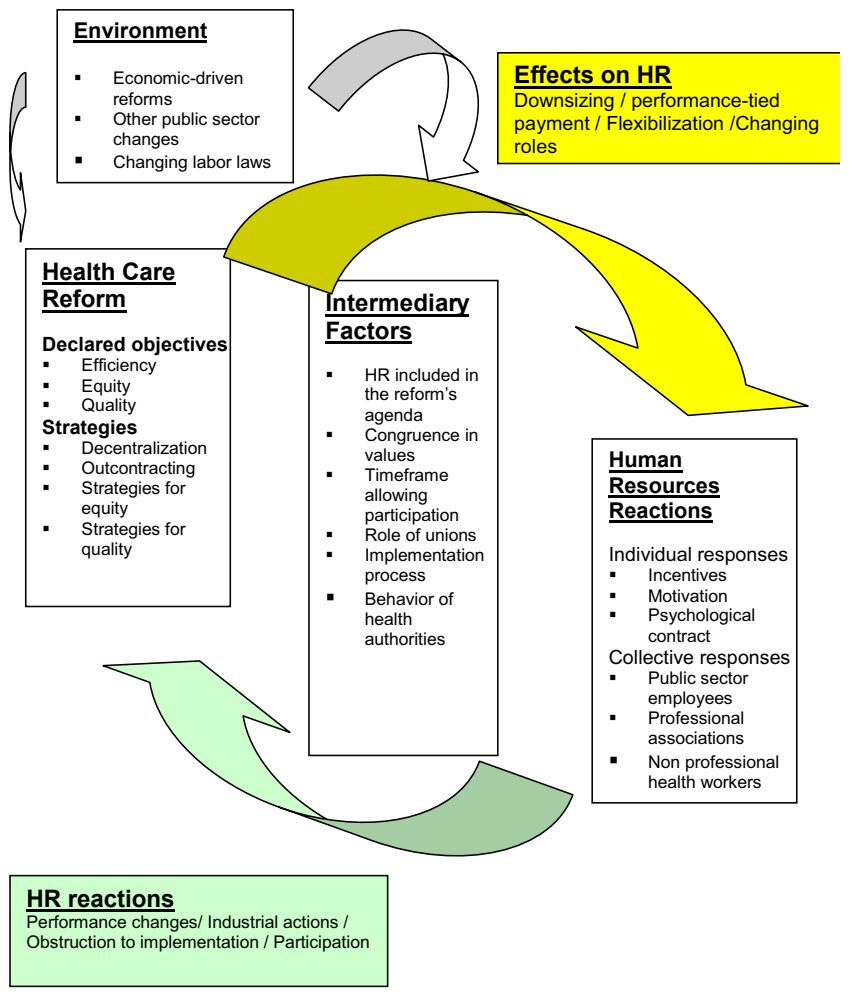

Figure 2

Factors mediating workforce-reform interrelationships.

Figure 2 illustrates these reciprocal influences between human resources and health sector reform.

The findings in Fig. 2 reveal a need to continue trying to fill the gaps of knowledge to improve the practice of human resources mobilization in reform processes. Further investigation is needed around unresolved issues such as:

- The influence of working conditions (stress, flexibility, outcontracting) on user's satisfaction (perceived quality), searching for evidence of quality diminution resulting from changing the working conditions in settings other than hospitals and nursing staff.

- How union and professional organizations' power is changing the level of employment in the health sector during the reform process.

- Characterization of the main intermediate factors that determine "paradoxical" responses to financial incentives aimed at changing doctors' practice.
- Collecting "best practices" in balancing workforce participation and attainment of objectives in real-world experiences, and finding the main environmental determinants in achieving this balance.

\section{Implications for policy design}

Two approaches or agendas in the development of human resources policies in countries undergoing health sector reform are superimposed [54,57]. The first one is what can be called the old agenda, which corresponds to issues generated by a model of stable and protected labor relations based on a lifetime career. The second approach or agenda is a new or flexible agenda, which responds to a new regulatory model characterized by the flexibility of labor and employment. The old agenda includes persistent problems that personnel administration has been unable to address. The new agenda refers primarily to situations and problems arising from the reforms.

Many countries, particularly in the developing world, have accumulated problems in solving the restraints posed by the old agenda. However, the reform processes have added new issues that became a burden too heavy to bear, decreasing their ability to cope with the overlapping challenges. The implementation of some "prescriptions" of the new agenda, such as decentralization or the introduction of new systems of incentives, has mobilized a great deal of the attention of human resources managers and policymakers, leaving less room to continue addressing previous shortcomings, such as strengthening health information system.

The transition to this new agenda, while keeping pace with the processes that the old one left unresolved, requires an integrated concept of the role of human resources factors in the health system as a whole. This concept should provide a clear vision of how the proposed configuration of the services will be affected by the human resources imbalances, and how to act to correct them. At the same time this integrated approach must be able to shape human resources policy, coherent with the values and health objectives of the reform, but with the flexibility to introduce the incentives and adjustments that the workforce requires to be continuously involved in the process.

The health authorities must build a human resources strategy into the reform process, including a consistent set of tools with organizational fit. Experience in other industries provides an insight into the impact of these strategies on overall performance, underlining the relationship between the different components of HR practices, the general attitudes of the firm and the global message that the firm transmits to its employees $[56,58]$. 
The human resources strategy is therefore integrated as a vital component of the policy design and planning, changing the role of the workforce specialist to a more political and strategic adviser, as part of the steering team of the reform. It also requires new capacities in the human resources units of the national health authorities [55], with information and monitoring roles in terms of developing a human resources information system. These new capacities should include: collecting and analyzing information about the reform process; a policy role in terms of developing an appropriate regulatory framework for health staff; and an advisory and guidance role in terms of providing technical assistance on workforce issues, and providing support for cultural changes.

These units should be able to:

- Build information systems to be able to measure the present and future human resource issues and trends.

- Gain trustworthiness to summon the participation of the representatives of the workforce towards clearly defined population health objectives.

- Be able to propose innovative and flexible ways of involving the workers in the new processes that should be coherent with the values and objectives of the health system.

- Maintain a bidirectional channel of communication between the policymakers and the representatives of those implementing the policies.

The construction of these new capacities is, at the same time, an urgent and long-term task that cannot be pressed, but that cannot be delayed.

\section{Competing interests}

None

\section{Authors' contributions}

The authors contributed equally to this work.

\section{Additional sources}

Main sources of data included electronic journals, online databases and gray literature. The search through bibliographic databases was performed using the following resources:

the Documentation System in Human Resources for Health (SIDORH), from Pan American Health Organization/World Health Organization http://www.ameri cas.health-sector-reform.org/sidorh/ the Virtual Library in Health from BIREME, http:// www.bireme.br/

the WHO Library database (WHOLIS) http:// dosei.who.int/uhtbin/cgisirsi/

Wed+Nov+21+23:21:20+MET $+2001 / 0 / 49$

the Observatory of Human Resources in the Health Sector Reform from Pan American Health Organization/World Health Organization, http://observatorio rh.tripod.com/ Observatory/

the WHO Global Health Workforce Strategy Group (GHWSG) documents, http://www.who.int/hrh/docu ments/HRH reports/en/index1.html

the World Bank online database, http://www1.world bank.org/hnp/hsd/humanresources index.asp

the Inter American Development Bank online and documentation system database, http://www.iadb.org/res/ index.cfm?fuseaction=publications.type

the cyberlibrary of gray literature in health reform from the Health Sector Reform Initiative (USAID-PAHO), http://www.americas.health-sector-reform.org/english/ clearinghouse.htm

the electronic Human Resources for Health Development Journal, from Thailand http://www.moph.go.th/ops/hrdj/

the online document database of Partnership for Health Reform http://www.phrproject.com/

the International Labour Organization documentation database, http://www.ilo.org/

Random searches were also performed in other organizations' databases and search engines (OVID http:// www.ovid.com/; ScienceDirect http://www.sciencedi rect.com/). In some cases these organizations do not provide direct links to non-affiliated users.

The search was conducted using keywords or Boolean expressions where a search engine was embedded in the database. The following keywords and expressions were used: workforce and reform; manpower and reform; labor relations and health; labor conditions and health; labor market and health; motivation and health; incentives and health; industrial action and health; conflict and health; human resources; stress; downsizing; psychological contract.

A title search was performed in online libraries and websites where no search engine is provided. 


\section{Acknowledgements}

The authors are grateful to Maria Cristina Franceschini, Pedro Brito and Cristina Puentes-Markides for reviewing this paper and for making useful editorial comments.

\section{References}

I. Martineau T, Martinez J: Rethinking human resources: an agenda for the millennium. Health Policy and Planning 1998 I3(4|3345-358 [http://heapol.oupjournals.org/cgi/reprint//3/4/ 345.pdf].

2. International Labour Organization: Terms of employment and working conditions in health sector reforms. Report for discussion at the Joint Meeting on Terms of Employment and Working conditions in Health Sector Reforms. Geneva; 1998 [http://www.ilo.org/public/english/dialogue/sec tor/techmeet/jmhsr98/jmhsrr.htm]

3. Brito P: Impacto de las reformas del sector salud sobre los recursos humanos y la gestión laboral. Revista Panamericana de Salud Publica 2000, 8(I-2049-54 [http://www.scielosp.org/sci elo.php?script $=$ sci arttext $\&$ pid $=$ S1020$49892000000700008 \& \operatorname{lng}=p t \& n r m=i s o]$

4. Guevara E, Mendias E: La reforma del sector salud y sus implicaciones para la práctica, la regulación y la educación en enfermería: un estudio de cinco países. Washington, DC: $\mathrm{PAHO}$ WHO; 200I. [Serie de desarrollo de recursos humanos, \#27.] Available at: http://www.americas.health-sector-reform.org/sidorh/textos I.htm

5. World Health Organization: Coordinated health and human resources development. WHO Technical Report Series 80I. Geneva, 1990.

6. Adams $O$, Hirschfeld $M$ : Human resources for health: challenges for the 2 I st century. World Health Statistics Quarterly 1998 , 5I(I):28-32

7. Friedberg E: Le Pouvoir et la Règle. Paris: Editions du Seuil; 1993

8. Saltman R, Figueras J: European Health Care Reform. Analysis of Current Strategies. Copenhagen: World Health Organization Regional Office for Europe 1997. [WHO regional publications. European series no. 72.]

9. Cassels A: Health sector reform: Key issues in developing countries. Journal of International Development 1995, 7(3):329-347.

10. Pan American Health Organization/World Health Organization) USAID: Methodology for Monitoring and Evaluation of Health Sector Reform in Latin America and the Caribbean. Washing ton, DC; 1998. http://www.americas.health-sector-reform.org/english/ Ihsrpren.pdf and: Pan American Health Organization/World Health Organization - USAID: Linea basal para el seguimiento y la evaluación de las reformas del sector salud en Latinoamerica y el Caribe. Washington, DC; 1998. http://www.americas.healthsector-reform.org/greylit/docs/S0272.pdf

II. Almeida C, Bazzani R, Pittman P: Investigación sobre reformas del sector salud en América Latina y el Caribe. Washington, DC PAHO/WHO - IDRC; 2001.

12. Bógus $C$, Westphal M, Fernandes $E$, Possa S: A reforma sanitária e os recursos humanos dos serviços locais de saúde: o caso de Vargem Grande Paulista. Educación Médica y Salud 1995, 29(I):20-3I.

13. Kolehmainen-Aitken $\mathrm{R}$ : Decentralization and human resources: implications and impact. Human Resources for Health Development Journal 1998, 2(I): [http://www.moph.go.th/ops/hrdj/Hrdj no3/ table contents.html].

14. Cherchiglia M: Terceirização do Trabalho nos Serviços de Saúde: Alguns Aspectos Conceituais, Legais e Pragmáticos. In Especialização em Desenvolvimento de Recursos Humanos em Saúde. CADRHU Natal. Edited by Lima JC \& Santana JP. Washington, DC: OPS/ OMS; 1999:367-385 [http://observatorio rh.tripod.com/observato rio-rh/id5.html].

15. Mills A, Broomberg J: Experiences of contracting: an overview of the literature. Geneva: World Health Organization; 1998. [Macroeconomics, Health and Development Series, no. 33.]

16. Reissman D, Orris P, Lacey R, Hartman D: Downsizing, role demands, and job stress. Journal of Occupational \& Environmental Medicine 1999, 4 I(4):289-293.

17. Donabedian A: Social responsibility for personal health services: An examination of basic values. Inquiry 1971, 8(2):3-19.

18. Commission d'Etude sur les services de santé et les services sociaux: Rapport et recommandations - Les Solutions émergentes. Québec: Gou- vernement du Québec; 2000 [http://www.cessss.gouv.qc.ca/pdf/fr/00109.pdf].

19. Pan American Health Organization/World Health Organization: Situación de los Componentes Educacionales en Proyectos Relacionados con los Procesos de Reforma del Sector Salud. Países Seleccionados. Región de las Américas. Washington, DC; 200I [http://observatorio rh.tri pod.com/observatorio-rh/id l0.html].

20. Biscoe G: Human resources: the political and policy context. Prepared for the Global Health Workforce Strategy Group. Geneva: World Health Organization; 200I [http://www.who.int/hrh/documents/en/ HR-policy.pdf].

21. Pan American Health Organization/World Health Organization: Factores Restrictivos para la Descentralización en Recursos Humanos. Washington, DC; 1999. [Serie Desarrollo de Recursos Humanos, \#16.] http://www.americas.health-sector-reform.org/ sidorh/textos I.htm

22. World Bank: Public Administration Reform: The scope of the Civil Service in OECD countries and in other countries in Central and Eastern Europe. Background note produced for the Russian Federation Government. Moscow; 200I.

23. Valverde JM, Trejos ME, Rosales C: Formas de contratación laboral en el sector salud de Costa Rica. In: Observatorio de Recursos Humanos en Salud en Costa Rica: Avances y Perspectivas, Ministerio de Salud, CCSS OPS/OMS. Washington, DC: Pan American Health Organization/World Health Organization; 2000 [http://www.americas.health-sec tor-reform.org/sidorh/textos I.htm].

24. Dovlo D: Health sector reform and deployment, training and motivation of human resources towards equity in health care: issues and concerns in Ghana. Human Resources for Health Development Journal 1998, 2(I): [http://www.moph.go.th/ops/hrdj/ Hrdj no3/table contents.html].

25. Adams O, Hicks V: Pay and non-pay incentives, performance and motivation. Prepared for the Global Health Workforce Strategy Group. Geneva: World Health Organization; 200I [http://www.who.int/ hrh/documents/en/pay non pay.pdf]

26. Maceira D, Murillo M: Social sector reform in Latin America and the role of unions. Washington, DC: Inter-American Development Bank 200I. [Research Department, Working Paper 456.] http:// www.iadb.org/res/publications/pubfiles/pubWP-456.pdf

27. Clark $P$, Clark $D$, Davis $D$, Shea $D$ : Healthcare reform and the workplace experience of nurses: implications for patient care and union organizing. Industrial \& Labor Relations Review 200I, 55(I): | 33-| 48 .

28. Needleman J, Buerhaus P, Potter V, Mattke S, Stewart M, Zelevinsky $\mathrm{K}$ : Nurse staffing and patient outcomes in hospitals. Final report for Health Resources Services Administration. Contract No. 230-99-002 I. Harvard School of Public Health. Washington, DC: Health Resources Services Administration; 200I [ftp://ftp.hrsa.gov//bhpr/nursing/staffstudy/ staffing-outcomes.pdf].

29. Dussault G, Dubois C-A: Human resources for health policies: a critical component in health policies. Human Resources for Health 2003 [http://www.human-resources-health.com/content///// I].

30. Surprenant CF, Solomon M: Predictability and personalization in the service encounter. Journal of Marketing 1987, 51 1:86-96.

31. Antonacopoulou E, Kandampully J: Alchemy: the transformation to service excellence. The Learning Organization 2000, 7(I):I3-22.

32. Becker G: Human capital: a theoretical and empirical analysis with special reference to education. 3rd edition. Chicago: The University of Chicago Press; 1993

33. Cherchiglia M, Girardi S, Vieira R, Marques R, da Rocha P, Pereira L: Remuneración y productividad: el caso de la Fundación Hospitalaria del Estado de Minas Gerais, Brasil, I992-I995. Revista Panamericana de Salud Publica 1998, 4(21 I2-120 [http:// www.scielosp.org/scielo.php?script $=$ sci arttext\&pid $=S 1020$ 49891998000800007\&lng=pt\&nrm=iso].

34. Forsberg E, Axelsson R, Arnetz B: Financial incentives in health care. The impact of performance-based reimbursement. Health Policy 2001, 58:243-262.

35. Cherchiglia M: Formas de pagamento e prática médica: teoria e evidências empíricas. Washington, DC: Pan American Health Organization/World Health Organization; 2002 [http://www.paho.org/ Portuguese/HSP/HSR/HSROI/sistpago practmed port.pdf].

36. Berwick D: Payment by capitation and the quality of care. New England Journal of Medicine 1996, 335( I 6): | 227-|23|. 
37. PricewaterhouseCoopers: HEALTHCAST 20I0. Smaller world, bigger expectations. 1999 [http://www.pwchealth.com/cgi-local/ hcregister.cgi?link=pdf/hc2010.pdf].

38. Cavanagh S: A 'new' psychological contract for nurses: some management implications. Journal of Nursing Management 1996, 4(2):79-83.

39. Bennett S, Franco L: Public sector health worker motivation and health sector reform: a conceptual framework. Partnership for Health Reform. Bethesda: Abt Associates; 1999. [Major Applied Research \# 5 Technical Paper No. I.]. [http://www.phrplus.org/phrmar5.html].

40. Franco L, Bennett S, Kanfer R: Health sector reform and public health worker motivation: a conceptual framework. Social Science and Medicine 2002, 54:1255-1266.

41. BNA Daily Labor Report: Attorney urges nurses to help in lawsuits in which patients harmed by understaffing. . April II 2002.

42. Lawler E, Mohrman S: Unions and the new management. Academy of Management Executive 1987, 1:293-300.

43. International Labour Organization: Joint meeting on human resource development in the public service in the context of structural adjustment and transition. Geneva; 1998 [http:// www.ilo.org/public/english/dialogue/sector/techmeet/imps98/].

44. Healy J, McKee M: Health sector reform in Central and Eastern Europe: the professional dimension. Health Policy and Planning 1997, I 2(4286-295 [http://heapol.oupjournals.org/cgi/reprint//2/4/ 286.pdf].

45. Freidson E: Profession of medicine: a study of the sociology of applied knowledge. New York: Dodd, Mead \& Company; 1970.

46. Nigenda G, Machado M-H: Modelos de regulación profesional de los médicos en América Latina: elementos teóricos para su análisis. Cadernos de Saude Publica 1997, 13(4): [http://www.sci elosp.org/scielo.php? script=sci arttext\&pid=s01023 IIX 19970004000| I\&Ing=en\&nrm=iso].

47. Almeida C: Médicos e assistência médica: Estado, mercado ou regulação? Uma falsa questão. Cadernos de Saúde Pública 1997 13(4): elo.php?script $=$ sci arttext\&pid $=\mathrm{SO} 102-$ 3 IIX 1997000400009\&Ing=pt\&nrm=iso].

48. Manga P: Avoiding fundamental reform: current cost containment strategies in Canada. Journal of Health and Human Services Administration 1998, 20(4):468-50 I.

49. Brito P, Granda E: Observatorio de los Recursos Humanos en Salud. Quito: Organización Panamericana de la Salud; 2000 [http:// observatorio rh.tripod.com/observatorio-rh/idl.html].

50. Martineau T, Buchan J: Human resources and the success of health sector reform. Human Resources for Health Development Journal 2000, 4(3): [http://www.moph.go.th/ops/hrdj/hrdjl l/HR-suc cess-Tim.htm]

51. Podhorzer M: Unhealthy money: health reform and the $\mathbf{1 9 9 4}$ elections. International Journal of Health Services 1995, 25(3):393-40।.

52. Starr $P$ : What happened to health care reform. American Prospect 1995, Winter:20-31.

53. Weil L: Organized labor and health reform: union interests and the Clinton plan. Public Health Policy 1997, $18(1): 30-48$.

54. Dal Poz MR: Human resources: a critical factor in health sector reform. Washington, DC: Pan American Health Organization/World Health Organization 1998. [Human Resources Development Series \# 8.] http://www.americas.health-sector-reform.org/sidorh/ textosl.htm

55. Bach S: HR and new approaches to public sector management: improving HRM capacity. Prepared for the Global Health Workforce Strategy Group. Geneva: World Health Organization; 200I [http://www.who.int/hrh/en//mproving hrm capacity.pdf].

56. Bamberger P, Meshoulam I: Human resource strategy. Formulation, implementation and impact. California: Sage Publications; 2000.

57. Brito P, Galin I, Novick M: Labor relations, employment conditions and participation in the health sector. WHO Workshop on Global Health Workforce Strategy. Annecy, France, 9-12 December 2000 Geneva: World Health Organization; 2000 [http://www.who.int/hrh/ documents/en/Labour relations.pdf].

58. Ferris G, Arthur M, Berkson H, Kaplan D, Harrell-Cook G, Frink D Toward a social context theory of the human resource management-organization effectiveness relationship. Human Resource Management Review I998, 8(3):235-264.
Publish with Bio Med Central and every scientist can read your work free of charge

"BioMed Central will be the most significant development for disseminating the results of biomedical research in our lifetime. "

Sir Paul Nurse, Cancer Research UK

Your research papers will be:

- available free of charge to the entire biomedical community

- peer reviewed and published immediately upon acceptance

- cited in PubMed and archived on PubMed Central

- yours - you keep the copyright 